\title{
The Relevance of the National Movement of Cash Waqf for Advancing the Sharia Economy in Modern Times in Indonesia: A Review Study
}

\author{
Prasetyono Hendriarto \\ Universitas Pakuan, Indonesia \\ Corresponding author email: prasetyono.hendriarto@gmail.com
}

\begin{abstract}
This study aims to determine the relationship between the movement of national waqf funds and Islamic leaders' efforts in advancing the Islamic economy in Indonesia. The success of the country's economy is inseparable from various economic movements in the community, including the national waqf fund movement. To prove a clear connection and understanding, we collected secondary data from various scientific publications that discuss the problem in question. Then we thoroughly criticized the phenomenological approach design guidelines for answering questions with elements of validity and reliability. Our analysis is strongly influenced by the theory of qualitative research methods of social studies. To facilitate this review study, we rely on data collection via Google online search and the Grammarly Premium app to report in the standard language of instruction for international publications. Finally, we can conclude that although waqf is not like zakat as the pillar of Islam, Islam aspires to the enormous potential of waqf to solve various economical problems in the sharia approach. In Islam's view, waqf has great potential, so that it needs attention to become an alternative solution for welfare.

Keywords---advancing economy, cash waqf, national movement, sharia economy.
\end{abstract}

\section{Introduction}

The poverty issue has always been a critical issue for every country. Every nation has its way or solution, even in Indonesia, to solve it. They provide ensuring social insurance through the introduction of the National Social Security Scheme in the health sector. The Islamic economic system is also one of such alternatives, provided that Islamic economics has two mechanisms that can sustainably solve social welfare issues, namely through Waqf (Rahman, 2010; Abdul-Rahman \& Gholami, 2020; Wilson, 1997). One of the pillars of this revolution in Islam concerning waqf is the character or qualities of a believer that other individuals, such as the Hadith of the Prophet SAW, would gain whether he is or does not appear (Hadith narrated by Ahmad \& Thabrani). Of course, all Muslims want to be the best people, chosen in the eyes of Allah with the maximum ability we have and contribute to anyone in need. Especially for those who can directly make the best contribution, but if there are no Muslims who have died) This is the secret of the prophet's hadith about three practices whose rewards will continue to flow until the end: almsgiving, Jariyah (Waqf), and prayer children who pray for their parents (Hadith narrated by Muslim).

Besides, waqf's legal status is the procedure of wakif law to detach and hand over part of his property to be used indefinitely or for a specific time in compliance with his interests in Islamic worship and general welfare according to sharia (Farhati \& Khisni, 2018). In other words, waqf is a part of Islamic law, which is highly recommended because the rewards that continue to flow endlessly until the end of time even continue to grow and have multiple benefits for the Islamic ummah. Some scholars also emphasize that the person who waits is a reflection of the climax of generosity, with the strength of his faith in loving Allah, the Prophet, and other Muslims are beyond their interests, for it is evident that those who have waqf have permitted the best assets they value to become Muslims' property. As commanded by Allah in the holy Koran, they have become the perfect virtue.

Abdul-Karim, (2010) is convinced that waqf also has outstanding potential for minimizing the Islamic ummah's justice and socio-economic challenges when investigated more closely. So Islam will invite its people to donate 
resources to support and side with the fellow ummah's needs by waqf, almsgiving. The Waqf assets cannot be reduced in value and cannot be sold, and cannot be inherited. Waqf has also played a crucial role in mitigating socioeconomic challenges and justice within the Islamic ummah during Islamic history. Because waqf tends to be an investment that does not run out of consumption, this charity can be developed into productive capital, which can finance religious life, such as establishing places of worship and building madrasas, Islamic boarding schools, or others. Waqf is also proven to be an instrument of social security to help the weak fulfill their daily needs in welfare, old age security, and education. Also, existing waqf items are varied, ranging from land waqf, cash waqf, waqf property, and even waqf insurance.

Looking at Indonesia's demographics, Purwanto et al. (2016) wrote that waqf's potential could be a turning point for the economic revival of the Islamic ummah in the Asian region because good management of productive economic waqf will significantly impact changes in the Indonesian people's socio-economic conditions, especially the Islamic ummah as the majority of the population. Waqf cannot be separated from the nation's economic development instrument. It can be seen from the potential of waqf assets in Indonesia reaching IDR 2,000 trillion, and the potential for cash waqf can reach IDR 188 trillion per year (assets in Indonesia reaching IDR 2,000 trillion, and the potential for cash waqf can reach IDR 188 trillion per year (Mohsin, 2013). For now, the government must make a breakthrough and vital maneuver in conducting education and socialization to the public in a more massive and structured manner. With Law No. 41 of 2004 concerning cash waqf, it is hoped that the government can encourage people to get used to waqf.

It turns out that if it can be adequately formulated with modern technology such as digital platforms, it continues to grow, including in the management of socio-religious finance. The presence of technology is believed to capture the great potential in Indonesia as a country with a majority Muslim population to be well managed. The potential is enormous, and only a few are being gathered (Suhaili \& Palil, 2016). stated that a website-based crowdfunding application could be a collaborative waqf solution. They believe that with the digitization of zakat activities, the process of collecting and distributing waqif results will be more comfortable and more transparent among Muslims. Especially in Islamic countries, they have started developing waqf and zakat digitization projects by involving several communities by receiving bank accounts and waqaf managers in banks with an automatic technology allowance system. Because with this sharia digital-based payment system, managers can provide services with ease for customers because they can pay zakat and manage it automatically from their savings. Sanusi \& Shafiai (2015) convinced that funds from the management of waqf assets collected would be distributed using profit-sharing technology to the Baitul Mal in many regional branches.

Manara et al. (2018) argue that the strategic paradigm of increasing zakat's poverty reduction ability through the crowdfunding-zakat method is fundamental in Indonesia. They stated that Islamic financial and social structures such as the waqf might be further developed in line with innovations. It will increasingly play a role in fostering different constructive practices, and it is correct to redistribute welfare to underprivileged Muslims. In the long term, this instrument is also expected to support the ummah's future economic growth. They are starting from reducing poverty, overcoming backwardness, and improving health and education quality to reducing social inequality. All have been tested in other Muslim countries. So there is nothing wrong if Indonesia imitates the effectiveness of waqf with the support of technology.

This result research report also supported by Bulut \& Korkut (2017) who see in the Islamic awakening era, the Islamic ummah began to emerge awareness of Islam in a full Islamic commitment that later emerged the term halal lifestyle. It is demonstrated by Muslim events that are increasingly busy, ranging from halal food and beverage items spread in numerous areas, not just mosques. However, Muslim fashion is also increasingly in demand, so that many Muslim women are wearing hijab and sharia finance, which is in demand for Muslims to avoid elements of usury, which is strictly prohibited in Islamic teachings. In the field of Islamic finance, it certainly creates philanthropic principles in addition to pursuing material benefits. This philanthropy is useful as a distribution of wealth, one of which is waqf (Mahat et al., 2015; Abdullah \& Yaacob, 2012; Ambrose et al., 2015). Waqf is a means of providing facilities that can be used publicly. Waqf has the advantage that waqf is wider (not limited) compared to zakat, which is absolute only for eight groups. The government is creating an autonomous agency in Indonesia that acts as a nazir on waqf property, the Indonesian Waqf Board. It proves the Islamic ummah's high knowledge of both its rights and duties.

\section{Challenges in waqf management}

Besides the enormous potential of waqf to improve the Islamic ummah's welfare, waqf is currently being intensively socialized to the community. Even though the Islamic ummah itself had already implemented it far before this 
country was born, waqf is good to be rethinking. However, behind the great potential for improving the Islamic ummah economy, it turns out that waqf also has several challenges for the management of Waqf in Indonesia. Majeed (2020) said at least six waqf challenges that need attention: Waqf land is unproductive, the manager's mindset is still traditional, cash waqf is not yet widespread, and the waqf program violates the legal basis and the law. Therefore, the socialization of waqf to the community is still a priority, according to Ali et al. (2018) which states that many aspects must be prioritized in Indonesia's management and governance of waqf assets.

For waqf to be more functional and useful in serving the ummah, waqf needs a new management structure because it requires stable management from time to time as a complicated management model. One of the alternative methods for poverty alleviation projects in Indonesia is supposed to be this. For instance, these projects require funding that the government does not entirely supply so that that waqf would be a competitive option of considerable potential. Therefore, the initiation of new funding sources for programs such as waqf must be pursued. There are sources of social funds that are socially and politically free in Islam's socio-economic definition, including land contributions and funds (Azha et al., 2013; Sukmana, 2020; Bire et al., 2019). Nazir, or cash waqf fund manager, receives funds from cash waqf suppliers in this concept and invests the money in the actual sector and any incentive for investment dependent on sharia needs to be initiated. For poverty alleviation projects. Nazir or Manage would then share the profits and benefits gained from these investments. Nazir is obligated to ensure that the sum of funds is smaller than the original amount. Nazir must also have high expertise and need a financial institution specializing in promoting the production of SMEs. We seek to construct the structure by using a system dynamics approach. For this issue, Khamis \& Salleh (2018) have proven that the efficiency of cash waqf management in Malaysia needs work to manage with more strict regulation and approach.

Challenges are somewhat different from one place to another. Additionally, from time to time, waqf continues to face difficulties, such that Islamic academics and economists find it is pointless to sustain establishing and strengthening the administration of waqf funds. One example is the emergence of a debate about whether a waqf giver can ask for his assets or funds back. Some scholars, such as Abu Hanife, think it can be done. However, other scholars, namely Abu Yusuf, disagree. He referred to the practices carried out by Rasulullah SAW and his companions that emphasized they gave up their donated assets for the sake of religion. Among the Hanafi School's leading academics, this divergence of opinion continues to emerge. In the end, given the cases that had been forwarded, the court saw the need to take a stand. Professor Murat disclosed that, by making a definite verdict, the court then interfered. Therefore, for that matter, we have conducted useful research in looking for national waqf potential in improving community economy in shariah approaches for Indonesian economic development.

\section{Method}

As stated above, this study's main objective is to find the point of the national movement's relevance to promote cash waqf to advance the Islamic economy in the era of modern technology. To answer this question, we chose a descriptive qualitative study design by reviewing many publications that examine waqf in poverty alleviation efforts in Indonesia. The first step we take is to collect relevant data and information. Next, we prepare and organize the data. Then we started reviewing the notes related to the theme. Before the document is ready, efforts to collect notes and other material for review. Then the initial code activity and the coding results, and finally, we revised if the data we reviewed was not relevant to the theme's study question. We will state these data as findings until we find validity and reliability data as suggested by Sgier (2012) in his study "Qualitative data analysis." Because this review relies on data, we get all data with online data from online searching and Google scholar and assisted by the Grammarly Premium writing editing application to display data and write better.

\section{Result}

In this section, we will present the results of the review on ten international publications, which we consider the findings of this tenth research to provide data on findings that answer our study questions with the theme of the national movement of the potential of waqf to advance a sharia economy in the era of Islamic awakening, especially in Indonesia. The following is a summary of the ten scientific journals we studied: 


\section{National Movement of Cash Waqf}

The finding of Merlinda et al. (2021) a part of the national movement to empower cash waqf as a source of microbusiness financing to strengthen the economy of rural communities in Gunung Kawi District, Malang Regency. The issues they studied proved to be a stimulus for local economic improvement by using cash waqf to finance microenterprises. By analyzing the role of cash waqf in strengthening the regional economy by empowering local communities, they have contributed to increased empowerment and strengthening of the local economy in duck cultivation and duck egg processing in Gunung Kawi Regency.

Shaikh et al. (2017) examined the application of waqf for social financing and Islamic economic development. Waqf donors are considered project participants, with waqf being represented; Due to the large membership in the current waqf program, the alternatives suggested are somewhat specific. This waqf management institution considers donors as representatives of the waqf business, supported by the accumulated waqf money so that donors are given the luxury to benefit from commercial projects built on waqf land. Due to the large membership involved in the current waqf program, the alternatives suggested are somewhat specific. The agency considers the Waqf business; This new cash waqf model combines the conventional approach where contributors only provide cash waqf without understanding how it is used. This problem usually arises due to a lack of mutual contact between the waqf giver and the waqf organization.

Similarly, Thoarlim et al. (2017) based their research on cash waqf deposits as a creative tool for socio-economic growth in Bangladesh for Islamic banking. Waqf money, which started far from Prophet Muhammad (saw), has become a source of funds for the ummah's growth. Twelve commercial banks, six Islamic banks, and six traditional banks in Bangladesh were analyzed. Waqf is channeled for educational, social, and cultural growth. Their study shows that voluntary savings and investment mobilization in this sector will help Islamic banking for Bangladesh's economic growth. This study identified goods and cash waqf deposit certificates for mudarabah and their contribution to Islam's socio-economic growth in Bangladesh. The results of this study were originally published in Bangladesh as part of a series on Islamic banking. Finally, she is happy to know that Bank Social Islami Limited in Bangladesh is a fully licensed Islamic bank and is committed to supporting Islamic banking in managing waqf funds.

Haneef et al. (2017) conveyed the development of Waqf in Indonesia through a SWOT analysis of waqf asset managers. They examined how the Indonesian waqf body, which was inaugurated by the President of Indonesia, has played a role as a coordinating institution for Nazirs in managing all assets and assets of waqf. Their study concludes that the waqf program is very potential because most Muslims have the opportunity to raise large amounts of money and land. Simultaneously, the weakness is the lack of awareness of the rich Islamic ummah to participate in waqf. Thus, their study results are expected to provide input and remind again how the benefits and roles of the latest waqf bodies prosper the Islamic ummah economy and waqf programs in Indonesia other countries.

Pitchay et al. (2018) examined the management of waqf land through the crowdfunding-waqf model in Malaysia. They aim to offer alternative means and better financing arrangements to improve the governance of waqf assets. Their findings have developed a governance model for waqf as a source of funds for waqf institutions. This alternative is envisioned to support waqf bodies to reduce setbacks in managing the land produced by the waqf. Their study involves a crowdfunding platform based on the exploration of literary discourse in the field of waqf.

The implication is that it will become an alternative financing budget for waqf managers for waqf land management. Another benefit is that it is hoped that the kingdom and policymakers, involving the crowdfunding model, can support the kingdom to save on expenses for managing waqf land.

Waqf optimization is also being carried out in Bangladesh as reviewed by Thoarlim et al. (2017) which has the theme of money waqf, the need for innovative ways of managing Waqf is an experience from other Islamic countries. This study attempts to answer the critical need to revive and organize the waqf prospect, which has become a sector with significant prospects for improving welfare, especially for less economically weak. Currently, waqf institutions in Bangladesh are stagnant because the unmanaged waqf assets are idle so that there is no benefit for the people who need them. This waqf study implies that there are things that are urgent to be addressed in reforming and restructuring the management of waqf with legal discourse and management of waqf so that waqf can contribute as a forum to stimulate further future projects that produce the latest innovations for the growth of waqf bodies in Bangladesh.

\section{Waqf for advancing the Sharia Economy}

The study of Aimi et al. (2015) also adds to the understanding of waqf's problem from the opportunities and challenges in Malaysia's neighboring country as a country that practices Islamic law. This study highlights that waqf 
is one of the critical sectors of sharia economic management efforts that have been proven to reduce a place's socioeconomic status. The official parliament in the Islamic country of Selangor has an Islamic social institution that plays a strategic role in managing the Waqf assets. The challenges there are the same as other places, namely the lack of awareness and understanding of residents so that they get adequate costs from existing waqf and some of the waqf problems described in this paper have become useful discussions to help the waqf forum faced by waqif administrators during implementation.

Latif et al. (2018) examined the waqf market's development and conceptualized waqf governance through regtech. Waqf is considered an intrinsic segment of the Islamic financial services sector as a charitable organization that can grow into an Islamic Shia social, financial market. Because in Islamic finance, the pursuit of profit has dominated social and financial equity targets. It is thus encouraging them not to overdo it. However, with properties worth more than a trillion dollars worth of credit to reach this target, these assets are neglected and left underdeveloped and unemployed due to governance issues regarding registration and the establishment, fraud identification, elimination, reporting, and enforcement. This study shows the capabilities of fintech-powered waqf are tech solutions in it are beneficial. Because Blockchain, cellular, and cloud infrastructure technology is being utilized to enable the growth of the social capital market, it can significantly help the Islamic economy towards a distinctive Islamic sharia economy and mutual prosperity.

Beik et al. (2019) examined the primary halal waqf blockchain model. In the modern era, waqf's ability can be increased by incorporating technological advances such as blockchain technology and cryptocurrency as long as it aligns with Islamic values, namely the Islamic economy, in governance, preparation, and distribution of waqf. Harmonization of blockchain technology in waqf organizations' operations is expected to direct an Islamic-based economy in the implementation of waqf, which will be more open to managers, waqf givers, recipients, and society as a whole. On the other hand, using a Sharia-compliant cryptocurrency can attract more Muslim communities, especially the young Islamic generation, to engage in waqf activities. As an unlimited cryptocurrency mechanism, waqf is predicted to be in demand by Muslim communities throughout the archipelago using the latest technology.

Ali et al. (2018) examine waqf, which is part of the Sustainable Development Goals (SDGs), and Maqasid alshariah program, Abdullah in this paper seeks to contextualize the potential role of waqf in the contemporary world; plural; Waqf, the eternal belief of Islam. He found that most of the 17 SDGs development goals are in line with sharia's long-term goals. So that waqf stakeholders have a good scope for developing a waqf-based development plan aligned with the SDGs framework.

\section{Discussion}

\section{The importance of the waqf program for economic prosperity}

This study's findings are necessary to present in this section of the discussion, summarized from the ten international publications we visited. Judging from its benefits, we can convey waqf, among other things, that waqf is a critical Islamic call, especially for those who are already wealthy or are already present. The goal is to unite the ummah by training Muslims' social soul who does good deeds with waqf's wisdom to help Muslims who need welfare. This goal is in line with the Pancasila principle, namely social justice for all nation components in many studies, including from Latif et al. (2018) on Pancasila, religion, nationality, and sociality among nations towards unity Soekarno's spirit. Besides training a soul sensitive to social conditions, waqf also teaches Muslims who are overweight that the goods in this world are not eternal. Therefore, they need to donate and share with others in need.

With this waqf, many lessons can be taken, especially for those who are already rich. This is in line with the caring system taught in many religious and social science contexts. This is in line with Furqon (2016) study of waqf assets as a solution to economic problems and the world of public education in Indonesia. In another context, waqf is also an uninterrupted practice as long as the waqf is beneficial for other Muslims. Through wealth waqf and whatever its objects will strengthen relationship and brotherhood efforts to prevent social disparities among the Islamic ummah and help the Islamic ummah national poverty alleviation program. This is also reviewed by Habtoor (2016) namely the implementation of supportive activities for poverty reduction solutions in the view of Islamic economics.

We can summarize that our study's findings on how the relevance of waqf with the effort to prosper the economy in an Islamic way is also part of the effort to succeed Islam's commandments with all the provisions and rules of doing charity. Suppose our study's findings found a significant intersection between efforts to collect waqf as part of realizing efforts to advance the Islamic economy. Furthermore, this is a significant finding to be disseminated Islamic 
ummah both as a candidate for waqf donors and the government as a waqf manager. The order to advance the economy in Islam is also the primary commandment in Islam as reviewed by Shomad (2017) namely that cases of Islamic law are part of normalizing the principles of sharia in law, which also regulates how the economy is run following the principles of sharia in Indonesia. Our findings also depart from the Islamic principle that in every property that is owned, of course, some belong to other people, especially those who are poor who are in dire need. The eternal afterlife can be saved through life on earth. Waqf helps us to get a better afterlife. The practice of waqf cannot be interrupted even after death if it is managed continuously.

\section{Conclusion}

Based on the study's discussion results to find the relevance of the potential movement of waqf in improving economic equality under Islamic sharia law in Indonesia. In the ten scientific publications that discuss waqf in various Islamic countries, it is evident that the waqf program that we studied, all of the results of their study, on average, believed that the waqf program was the most appropriate solution to improve the Islamic sharia-based economy. It cannot be denied that efforts towards Islamic economic prosperity through waqf have brought opportunities and challenges for the Islamic ummah in managing waqf assets to bring the results desired by the waqf law itself. Therefore, a similar study is needed, which explores solutions to minimize challenges and raise hopes and opportunities so that efforts to advance the economy under the umbrella of Islamic sharia can be successful.

\section{Acknowledgments}

The authors thank all feedback and authorship support from all seniors in the faculty departments where we work. Likewise, the financial support is beneficial for the study's implementation so that the process of reporting this study is following the plan. Our paper will not go smoothly without the support of our colleagues and seniors on the theme of our study, "The Relevance of the National Movement of Cash Waqf for Advancing the Sharia Economy in Modern Times in Indonesia: A Review Study."

\section{References}

Abdul-Karim, S. (2010). Contemporary shari'ah structuring for the development and management of waqf assets in Singapore [PhD Thesis]. Durham University.

Abdul-Rahman, A., \& Gholami, R. (2020). Islamic Finance and COVID-19 Recovery: The Role Profit-Loss Sharing Contract. Jurnal Pengurusan (UKM Journal of Management), 59.

Aimi, N. M. P., Nurauliani, J. R., \& Shahdila, W. S. (2015). Issues and challenges of waqf instrument: A case study in mais Warees Investment Pte Ltd available at www. warees. com. Online Accessed (April 2015).

Abdullah, A., \& Yaacob, H. (2012). Legal and Shariah issues in the application of Wakalah-Waqf model in Takaful industry: an analysis. Procedia-Social and Behavioral Sciences, 65, 1040-1045. https://doi.org/10.1016/j.sbspro.2012.11.239

Ambrose, A. H. A. A., Aslam, M., \& Hanafi, H. (2015). The possible role of waqf in ensuring a sustainable Malaysian federal government debt. Procedia Economics and Finance, 31, 333-345. https://doi.org/10.1016/S2212-5671(15)01205-8

Azha, L., Baharuddin, S., Salahuddin, S. S., \& Afandi, M. R. (2013). The practice and management of Waqf education in Malaysia. Procedia-Social and Behavioral Sciences, 90, 22-30. https://doi.org/10.1016/j.sbspro.2013.07.061

Ali, K. M., Yuliani, M., Mulatsih, S., \& Abdullah, Z. (2018). Aspek-Aspek Prioritas Manajemen Wakaf di Indonesia. AL-FALAH: Journal of Islamic Economics, 3(1), 1-28.

Beik, I. S., Zaenal, M. H., \& Rizkiningsih, P. (2019). Waqf Led Halal Cryptocurrency Model. In Halal Cryptocurrency Management (pp. 285-298). Springer.

Bire, A. R., Sauw, H. M., \& Maria, M. (2019). The Effect of Financial Literacy towards Financial Inclusion through Financial Training. International Journal of Social Sciences and Humanities, 3(1), 186-192.

Bulut, M., \& Korkut, C. (2017). A look at cash waqfs as islamic financial institutions and instruments. In Critical Issues and Challenges in Islamic Economics and Finance Development (pp. 85-96). Springer.

Farhati, D., \& Khisni, A. (2018). Legal Review Of Implementation Endowments Authority Relating To The Under Hand Agreement Made By Waqif (Case Study In Kua Wonosalam, Demak). Jurnal Akta, 5(3), 773-776. 
Furqon, A. (2016). PENGELOLAAN WAKAF TANAH PRODUKTIF: Studi Kasus Nazhir Badan Kesejahteraan Masjid (BKM) Kota Semarang dan Yayasan Muslimin Kota Pekalongan. Al-Ahkam, 26(1), 93-116.

Habtoor, N. (2016). Influence of human factors on organisational performance. International Journal of Productivity and Performance Management.

Haneef, M. A. M., Kamil, N. K. B. M., \& Ayuniyyah, Q. (2017). Development of Waqf in Indonesia: The Swot Analysis of Indonesia Waqf Board (Bwi). Al-Infaq: Jurnal Ekonomi Islam, 8(2), 136-150.

Khamis, S. R., \& Salleh, M. C. M. (2018). Study on the efficiency of cash waqf management in Malaysia. Journal of Islamic Monetary Economics and Finance, 4(1), 61-84.

Latif, S. A., Din, N. M. N., \& Mustapha, Z. (2018). The role of good waqf governance in achieving sustainable development. Environment-Behaviour Proceedings Journal, 3(7), 113-118.

Majeed, A. A. (2020). Activating" Waqf" and" Zakat" in Tackling Poverty and Supporting Investment in Palestine: Chances and Challenges.

Manara, A. S., Permata, A. R. E., \& Pranjoto, R. G. H. (2018). Strategy model for increasing the potential of zakat through the crowdfunding-zakat system to overcome poverty in Indonesia. International Journal of Zakat, 3(4), $17-31$.

Merlinda, S., Qurrata, V. A., Yusida, E., Purnamasari, V., Seprillina, L., \& Hussain, N. E. (2021). The Role of Cash Waqf as a Source of Micro Business Financing for Strengthening the Local Economy: A Case Study in Gunung Kawi District, Malang Regency. Review of Integrative Business and Economics Research, 10, 136-144.

Mohsin, M. I. A. (2013). Financing through cash-waqf: A revitalization to finance different needs. International Journal of Islamic and Middle Eastern Finance and Management.

Mahat, M. A., Jaaffar, M. Y., \& Rasool, M. S. A. (2015). Potential of Micro-Waqf as an Inclusive Strategy for Development of a Nation. Procedia Economics and Finance, 31, 294-302. https://doi.org/10.1016/S22125671(15)01193-4

Pitchay, A. A., Thaker, M. A. M. T., Mydin, A. A., Azhar, Z., \& Latiff, A. R. A. (2018). Cooperative-waqf model: A proposal to develop idle waqf lands in Malaysia. ISRA International Journal of Islamic Finance.

Purwanto, Y., Utomo, H., \& Noor, R. (2016). Nāzir Al-Waqf in Imam Syafi'i's View and Its Implementation in Indonesia. International Journal of Nusantara Islam, 4(1), 49-62.

Rahman, A. R. A. (2010). Islamic microfinance: An ethical alternative to poverty alleviation. Humanomics.

Sanusi, S., \& Shafiai, M. H. M. (2015). The management of cash waqf: Toward socio-economic development of Muslims in Malaysia. Jurnal Pengurusan (UKM Journal of Management), 43.

Sgier, L. (2012). Qualitative data analysis. An Initiat. Gebert Ruf Stift, 19, 19-21.

Shaikh, S. A., Ismail, A. G., \& Shafiai, M. H. M. (2017). Application of waqf for social and development finance. ISRA International Journal of Islamic Finance.

Sukmana, R. (2020). Critical assessment of Islamic endowment funds (Waqf) literature: lesson for government and future directions. Heliyon, 6(10), e05074. https://doi.org/10.1016/j.heliyon.2020.e05074

Shomad, A. (2017). Hukum Islam: Penormaan Prinsip Syariah dalam Hukum Indonesia. Kencana.

Suhaili, N. A., \& Palil, M. R. (2016). Crowdfunding: A collaborative waqf based internet platform. International Journal of Business, Economics and Law, 11(5), 2289-1552.

Thoarlim, A., Rahman, M., \& Yanya, A. (2017). Cash waqf in Bangladesh and the need for innovative approach towards Awqaf: Lessons from selected countries. International Journal of Academic Research in Business and Social Sciences, 7(4), 151-169.

Wilson, R. (1997). Islamic Finance and Ethical Investment. International Journal of Social Economic, 24(11), 13251342. 